\title{
Biomass equations for European beech growing on dry sites
}

\author{
Tamalika Chakraborty ${ }^{(1)}$, \\ Somidh Saha ${ }^{(2)}$, \\ Albert Reif ${ }^{(1)}$
}

\begin{abstract}
Biomass equations for European beech (Fagus sylvatica L.) trees growing on dry sites have not been published, although such equations are needed for a proper estimation of the biomass of beech trees growing naturally at their drought limit in dry forests. We aimed to: (1) develop new allometric aboveground biomass equations for European beech trees growing on dry sites; (2) compare these equations with existing biomass equations. We harvested 86 plants, ranging from saplings to trees, from forest stands on south-facing slopes at 5 locations in Germany and Switzerland. Whole plant weights were measured in the field after felling, and samples from stem, branches and leaves of every harvested plant were brought to the laboratory. We developed diameter- and height-based regression equations for the total above-ground biomass, stem with bark biomass, and biomass of the branches with leaves and further compared them with the existing equations from the literature. Our results showed that the 5 current diameter-based equations available in the literature significantly overestimate the total above-ground biomass, the stem with bark biomass and the biomass of branches and leaves. With increasing tree size, the proportion of the biomass of branches and leaves to the total tree biomass decreased significantly. We also found that the inclusion of height in biomass models did not influence the prediction of total aboveground biomass, but significantly improved the prediction of stem biomass. We recommend that researchers and foresters use the equations developed in this study to quantify the biomass of beech trees growing under similar site conditions.
\end{abstract}

Keywords: Above-ground Biomass, Stem Biomass, Abandoned Oak Coppiced Forest, Stunted Growth, Plant Size Allometry to be several thousand $\mathrm{km}^{2}$ (Suchomel et al. 2012), located mostly in the hilly terrains in the states of Baden-Württemberg, Bavaria, Rhineland-Palatinate and Hesse; the areas are owned by state, private, and community organizations, such as municipalities. The actual area of such forests is difficult to ascertain because most privately owned forests are not inventoried by the National Forest Inventory of Germany. In Switzerland, abandoned coppiced forests dominated by oaks can be found mainly in Jura, Plateau and the Pre-Alps regions. The area of such forests is nearly 5400 ha, $2.4 \%$ of the stocked forests in these three regions of Switzerland (WSL 2015).
(1) Chair of Vegetation Science, Faculty of Environment and Natural Resources, University of Freiburg, Tennenbacherstr. 4, D-79085 Freiburg (Germany); (2) Chair of Silviculture, Faculty of Environment and Natural Resources, University of Freiburg, Tennenbacherstr. 4, D79085 Freiburg (Germany)

@ Tamalika Chakraborty (tamalika.chakraborty@waldbau.uni-freiburg.de)

Received: Sep 21, 2015 - Accepted: Mar 30, 2016

Citation: Chakraborty T, Saha S, Reif A (2016). Biomass equations for European beech growing on dry sites. iForest 9: 751-757. - doi: 10.3832/ifor1881-009 [online 2016-06-17]

Communicated by: Giorgio Alberti
Sessile (Quercus petraea [Matt.] Liebl.) and downy (Quercus pubescens Wild.) oak commonly dominate the abandoned coppiced forests of central Europe. Nevertheless, due to the cessation of forest management activities in the 1940s, natural succession has been taking place in these stands (Sayer 2000, Kohler et al. 2006). European beech (Fagus sylvatica L.) is one of the most common and dominant tree species in central European forests, with a high level of shade tolerance and a wideranging geographic distribution (Ellenberg 2009, BMEL 2014), growing naturally from seeds under the canopy of oak-dominated abandoned coppiced forests. Natural regeneration of beech trees in oak coppiced forests is more prominent in ecotones where oak coppiced forests and beechdominated forests overlap on the hillslopes (Sayer 2000, Kohler et al. 2006, Gärtner et al. 2008).

Species-specific biomass equations for trees are vital to accurately estimate the biomass and productivity of forests. Variation in biomass within species occurs due to changes in site quality and management practices (Peuke et al. 2002, Coll et al. 2004). Site-specific biomass equations for oak trees growing in abandoned aged coppiced forests were recently developed (Suchomel et al. 2012), but the existing biomass equations for beech trees were 


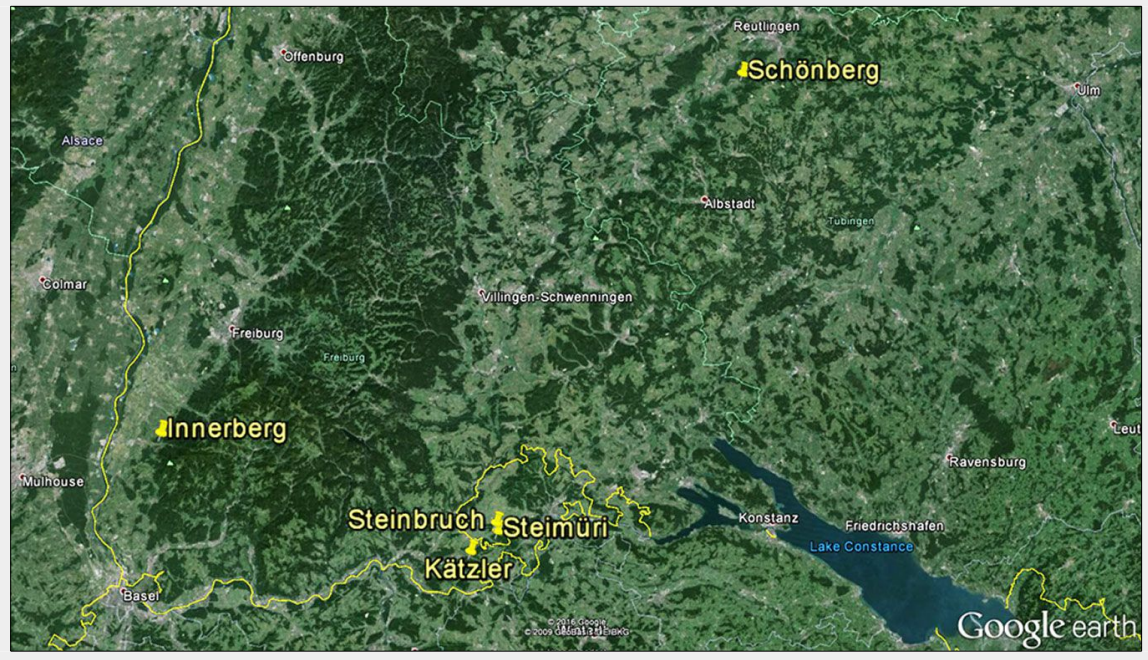

Fig. 1 - Locations of the study sites in Germany and Switzerland (yellow pins). Map source: Google Earth ${ }^{\oplus}$.

mostly established from trees harvested in high forests from moist and fertile sites. The equations were primarily built for $\mathrm{CO}$ dominant and dominant trees, often with $\mathrm{DBH}$ (diameter at $1.3-\mathrm{m}$ height) ranging from 7 to $80 \mathrm{~cm}$ or more (Zianis et al. 2005). However, beech trees growing in abandoned oak coppiced forests on dry, south-facing sites would not reach such dimensions due to the dense oak overstory and low water availability. Biomass equations from beech trees from these types of forests are still lacking in the literature. In this study, we aimed to present new biomass equations (above-ground biomass or "AB", stem with bark biomass or "ST", and branch with leaf biomass or "BR") for European beech trees growing in abandoned oak coppiced forests on dry sites. In addition, we tested how the proportion of stem and branch biomass to the total above-ground biomass changed with tree size in such forests.

\section{Materials and methods}

Study sites and management history

We selected abandoned coppiced forest stands from 5 locations in southern Ger- many and northern Switzerland (Fig. 1). These five stands were located in southern aspects with slope ranging from $16^{\circ}$ to $31^{\circ}$, thus receiving high solar irradiation. The stands had not been commercially managed since the end of World War II, and beech trees were naturally regenerating by seed at their drought limit under the canopy of oaks (Gärtner et al. 2008). These stands have rendzina soil and were formed on Jurassic limestone (Tab. 1). More detailed description of the sites' characteristics can be found in Sayer (2000), Kohler et al. (2006) and Gärtner et al. (2008).

\section{Sampling design}

The average stand size was 0.6 ha, ranging from 0.3 to 0.9 ha. In each stand, at least three $400 \mathrm{~m}^{2}$ plots were established, with a total number of 19 plots. We dug soil profiles in each plot to calculate the available soil water storage capacity (ASWSC) and to ascertain the magnitude of dryness in the stand level (see Chakraborty 2010 for the ASWSC calculation procedures used). The stand-level mean values of ASWSC in all five forest stands ranged from 50 to 76 $\mathrm{mm}$ (Tab. 1). Forest sites having ASWSC in this range were classified as "very dry" to "dry" sites according to the Forest Site Classification of Germany (Standortskartierung 2003). In the summers of 2012 and 2013, we inventoried all of the beech saplings and trees growing in those plots. In total, 230 beech saplings and trees were found and inventoried. We classified plants as "saplings" if they were approximately 2 $\mathrm{cm}$ in diameter at a 1.3-m height from the ground or thinner in diameter within the height limit of $1.5 \mathrm{~m}$, as reported in the guidelines provided in National Forest Inventory of Germany (BMEL 2014). All of the plants taller than $1.5 \mathrm{~m}$ with a diameter at $1.3 \mathrm{~m}(\mathrm{DBH})$ of more than $2 \mathrm{~cm}$ were classified as trees. The dendrometric information of those 230 plants are provided in Tab. S1 (Supplementary material). The 230 plants were further categorized into two size classes: saplings and trees. The diameter measured at root collar (DRC, taken at $5 \mathrm{~cm}$ above ground) in saplings ranged from 1.1 to $4.1 \mathrm{~cm}$, whereas the DBH of trees ranged from 2 to $18 \mathrm{~cm}$. Considering this stand-level dendrometric information, we selected 86 plants out of the 230 plants to be harvested for developing the biomass equations. Because the stands were located on dry sites, we observed stunted growth in beech trees and saplings while gathering our inventory data. It is worth noting that Chakraborty et al. (2013) showed that beech saplings with a DRC of $4.1 \mathrm{~cm}$ could be as old as 42 years when growing in dry, south-facing forests. To address the phenomenon of stunted growth, we decided to create two sets of biomass equations for the 86 harvested plants: (1) 20 saplings for which the DRC and height were considered to be the independent variables for biomass model construction and parameter estimation, termed the "DRC category" and designated as "shorter plants"; (2) 66 trees for which DBH and height were considered to be the independent variables for biomass model construction and parameter estimation, termed the "DBH category" and designated as "taller plants". The range of the DRC and DBH of 86 plants were 1.1-4.1 cm and 2-18 cm, respectively. The mean diameter, height, and height/DRC ratio for the shorter trees were $2 \mathrm{~cm}, 1.8 \mathrm{~m}$ and 89 , respectively, with

Tab. 1 - Description of the study sites. (MAT): mean annual temperature; (MAP): mean annual precipitation; (ASWSC): available soil water storage capacity; (1): as in Gauer \& Aldinger (2005); (2): latitude and longitude are given in decimal degrees.

\begin{tabular}{|c|c|c|c|c|c|c|c|c|c|c|c|}
\hline $\begin{array}{l}\text { Study } \\
\text { site }\end{array}$ & $\begin{array}{l}\text { Stand } \\
\text { code }\end{array}$ & $\begin{array}{l}\text { Region } \\
\text { (Growing zone / Growing district) }^{1}\end{array}$ & $\begin{array}{l}\text { Long } \mathrm{E} \\
\text { Lat } \mathrm{N}^{2}\end{array}$ & $\begin{array}{l}\text { Altitude }^{1} \\
\text { (m a.s.l.) }\end{array}$ & $\begin{array}{l}S^{S i z e}{ }^{1} \\
\text { (ha) }\end{array}$ & $\begin{array}{l}\mathrm{MAT}^{1} \\
\left({ }^{\circ} \mathrm{C}\right)\end{array}$ & $\begin{array}{l}\mathrm{MAP}^{1} \\
(\mathrm{~mm})\end{array}$ & $\begin{array}{l}\text { Days > } \\
10{ }^{\circ} \mathrm{C}\end{array}$ & $\begin{array}{c}\text { Slope } \\
\text { angle }^{1}\left({ }^{\circ}\right)\end{array}$ & $\begin{array}{l}\text { Aspect }^{1} \\
\left({ }^{\circ}\right)\end{array}$ & $\begin{array}{c}\text { ASWSC }^{1} \\
(\mathrm{~mm})\end{array}$ \\
\hline $\begin{array}{l}\text { Innerberg } \\
\text { (D) }\end{array}$ & IN & $\begin{array}{l}\text { Oberrheinisches Tiefland und } \\
\text { Rhein-Main-Ebene/Markgräflerland }\end{array}$ & $\begin{array}{r}7.67 \\
47.81\end{array}$ & 524 & 0.9 & 9.7 & 934 & 177 & 23 & $155-180$ & 58 \\
\hline $\begin{array}{l}\text { Schönberg } \\
\text { (D) }\end{array}$ & SOB & $\begin{array}{l}\text { Schwäbische Alb/Traufzone } \\
\text { der Mittleren Alb }\end{array}$ & $\begin{array}{r}9.12 \\
48.42\end{array}$ & 781 & 0.8 & 7.1 & 1067 & 143 & 31 & $205-243$ & 76 \\
\hline $\begin{array}{l}\text { Kätzler } \\
\text { (D) }\end{array}$ & KAT & $\begin{array}{l}\text { Südwestdeutsches } \\
\text { Alpenvorland/Klettgau }\end{array}$ & $\begin{array}{r}8.43 \\
47.62\end{array}$ & 566 & 0.3 & 8.6 & 1049 & 164 & 30 & $185-228$ & 53 \\
\hline $\begin{array}{l}\text { Steimüri } \\
(\mathrm{CH})\end{array}$ & SMU & $\begin{array}{l}\text { Südwestdeutsches } \\
\text { Alpenvorland/Klettgau }\end{array}$ & $\begin{array}{r}8.50 \\
47.65\end{array}$ & 584 & 0.5 & 8.6 & 1049 & 164 & 24 & $251-280$ & 52 \\
\hline $\begin{array}{l}\text { Steinbruch } \\
\text { (CH) }\end{array}$ & SBR & $\begin{array}{l}\text { Südwestdeutsches } \\
\text { Alpenvorland/Klettgau }\end{array}$ & $\begin{array}{r}8.50 \\
47.67\end{array}$ & 643 & 0.4 & 8.6 & 1049 & 164 & 16 & $210-220$ & 50 \\
\hline
\end{tabular}


standard deviations of $0.9,0.8$ and 28 , respectively; the mean diameter, height, and height/DBH ratio for the taller trees were $8.7 \mathrm{~cm}, 9 \mathrm{~m}$ and 112, respectively, with standard deviations of 4, 3 and 27, respectively (Tab. S2 and Tab. S3 in Supplementary material).

\section{Plant harvesting and weighing in the \\ field and laboratory}

After felling, the plant height and height to the crown base (height of the lowest living foliage) was measured. The fresh weight of the whole tree ( $A B$ fresh) was measured directly in the field using a portable spring scale ( $0.5 \mathrm{~kg}$ accuracy). The tree was then separated in two different portions: the main stem with bark and without branches (ST_fresh) and all the branches with leaves (BR_fresh). The fresh weight of ST and BR were measured in the field. Depending on the height, the tree crown was vertically divided into three equal compartments. Sub-samples were collected for further analysis in the following steps: (1) stem disks of a 10-cm length were first cut at $10 \mathrm{~cm}$ above ground and then at 1-meter intervals until the tip of the tree; (2) three randomly chosen branches were collected from each of the three vertical crown compartments; and (3) the fresh weight of individual disks and branches was measured in the field using portable electronic scales (accuracy $0.001 \mathrm{~kg}$ ). Finally, samples collected in the field were brought to the laboratory for an accurate dry biomass calculation by determining the moisture content.

Collected disks were weighed after drying in the oven at $105{ }^{\circ} \mathrm{C}$ until a constant weight was achieved. Similarly, sample branches with leaves were chipped and dried in oven at $105^{\circ} \mathrm{C}$. The dry weight of the $n^{\text {th }}$ stem $\left(\mathrm{ST}_{n}\right)$ or branch $\left(\mathrm{BR}_{n}\right)$ was calculated as follows (eqn. 1):

$$
T_{D W}\left(S T_{n} \vee B R_{n}\right)=\frac{X_{d r y}}{X_{f r e s h}} \cdot T_{F W}\left(S T_{n} \vee B R_{n}\right)
$$

where $T_{\mathrm{DW}}$ and $T_{\mathrm{FW}}$ are the total dry weight and the total fresh weight, respectively, and $X_{\text {dry }}$ and $X_{\text {fresh }}$ are the dry and fresh weights of the stem (ST) or branch (BR), respectively. Finally, the total aboveground biomass of each of the 86 plants were calculated as the sum of the dry weights of stems with bark and branches including leaves (Tab. S2 and Tab. S3 in Supplementary material).

\section{Parameterization of biomass models and statistical analysis}

The biomass models were developed, compared, and validated in four consecutive steps:

1. we developed diameter-based biomass equations (separately for fresh and dry biomass) based on the power function that is commonly used to estimate biomass: $\mathrm{Y}=a \cdot \mathrm{D}^{\mathrm{b}}$, where $\mathrm{Y}$ is the biomass, $\mathrm{D}$ is either the DBH or DRC, and $a$
Tab. 2 - Allometric equations (for the DRC category) for predicting fresh and dry biomass for different trunk compartments as well as for the total above-ground fresh and dry biomass for beech saplings growing on dry sites. All the models are based on the power function equation: biomass $(\mathrm{kg})=a \cdot \mathrm{DRC} \cdot(\mathrm{AB})$ : total above-ground biomass; (ST): stem with bark biomass; (BR): branch biomass including foliage; (SE $a$ ): standard error of coefficient $a$; (SE $b$ ): standard error of coefficient $b$.

\begin{tabular}{|c|c|c|c|c|c|c|c|c|}
\hline \multirow{2}{*}{$\begin{array}{l}\text { Biomass } \\
\text { component }\end{array}$} & \multirow{2}{*}{ Equation } & \multicolumn{4}{|c|}{ Coefficients } & \multirow{2}{*}{$\operatorname{Adj}-R^{2}$} & \multirow{2}{*}{ P-value } & \multirow{2}{*}{$N$} \\
\hline & & $a$ & SE $a$ & $b$ & SE $b$ & & & \\
\hline \multirow[t]{2}{*}{$A B$} & Fresh & 0.073 & 0.014 & 2.415 & 0.244 & 0.84 & $<0.001$ & 20 \\
\hline & Dry & 0.04 & 0.008 & 2.408 & 0.248 & 0.83 & $<0.001$ & 20 \\
\hline \multirow[t]{2}{*}{ ST } & Fresh & 0.027 & 0.006 & 2.412 & 0.304 & 0.77 & $<0.001$ & 20 \\
\hline & Dry & 0.019 & 0.005 & 2.199 & 0.317 & 0.71 & $<0.001$ & 20 \\
\hline \multirow[t]{2}{*}{ BR } & Fresh & 0.043 & 0.01 & 2.408 & 0.295 & 0.78 & $<0.001$ & 20 \\
\hline & Dry & 0.02 & 0.005 & 2.533 & 0.312 & 0.77 & $<0.001$ & 20 \\
\hline
\end{tabular}

and $b$ are the model constant and coefficient, respectively. The biomass predicted from DBH-based models was used to compare the existing biomass equations of beech trees. We found five published equations for European beech trees (Bartelink 1997, Cienciala et al. 2005, Pretzsch 2000, Santa-Regina et al. 1997, Stankic et al. 2014). We selected equations from literature that covered the $\mathrm{DBH}$ range of the European beech trees harvested in this study $(2-18 \mathrm{~cm})$;

2. we log transformed DRC, DBH and biomass to remove heteroscedasticity and nonlinear trends in the data. We performed linear regression analysis to develop biomass equations using biomass as a function of DBH or DRC;

3. we added the height of the tree as a covariate in the equations, even though the tree heights were correlated with their respective diameters (see Fig. $\mathrm{S} 1$ in Supplementary material); however, we decided to use both variables in the estimation of biomass and volume because the deviation between these variables may vary with age, site quality, stand composition and density;

4. finally, we calculated the root mean squared error (RMSE) for both equations (i.e., with or without tree heights). RMSE indicates the unexplained variation between modelled and observed values for the smallest to largest trees of the entire population. The equation with the low- est RMSE and highest adjusted $R^{2}$ values provides the best prediction.

The equations were validated by comparing modelled vs. observed values. The Shapiro-Wilk test was used to verify whether the data followed the normal distribution. Nonparametric tests, such as Spearman's $\rho$ correlation analysis and the Wilcoxon's signed rank test, were used when the data were not normally distributed. Otherwise, Pearson's $r$ correlation analysis and pair-sampled t-test were used. The equations were accepted when modelled and observed values in biomass did not differ significantly. Statistical analyses were performed by statistical package SPSS $v$. 20.0 (IBM 2011).

\section{Results}

DRC- and DBH-based biomass equations In all of the allometric equations for fresh and dry biomass calculated for the DRC category, the adjusted $R^{2}$ values were significantly high (adj- $R^{2} \geq 0.7-$ Tab. 2 ). The predicted biomass values were not significantly different from the observed ones (Wilcoxon signed-rank test - Tab. $\mathrm{S}_{4}$ in Supplementary material). The adjusted $R^{2}$ values were significantly high (adj- $R^{2} \geq 0.8$ ) for all of the allometric equations for fresh and dry biomass in trees where the DBH was used as biomass predictor (Tab. 3). Again, the predicted biomass values were not significantly different from the ob-
Tab. 3 - Allometric equations (for the DBH category) for predicting fresh and dry biomass for different trunk compartments as well as for the total above-ground dry and fresh biomass for beech trees growing on dry sites. All of models are based on the power function equation: biomass $(\mathrm{kg})=a \cdot \mathrm{DBH}^{\mathrm{b}}$. $(\mathrm{AB})$ : total above-ground biomass; (ST): stem biomass with bark; (BR): branch biomass including foliage; (SE $a$ ): standard error of coefficient $a$; (SE $b$ ): standard error of coefficient $b$.

\begin{tabular}{|c|c|c|c|c|c|c|c|c|}
\hline \multirow{2}{*}{$\begin{array}{l}\text { Biomass } \\
\text { component }\end{array}$} & \multirow{2}{*}{ Equation } & \multicolumn{4}{|c|}{ Coefficients } & \multirow{2}{*}{ Adj- $R^{2}$} & \multirow{2}{*}{ P-value } & \multirow{2}{*}{$N$} \\
\hline & & $a$ & SE $a$ & $b$ & SE $b$ & & & \\
\hline \multirow[t]{2}{*}{$A B$} & Fresh & 0.353 & 0.052 & 2.154 & 0.070 & 0.94 & $<0.001$ & 66 \\
\hline & Dry & 0.201 & 0.029 & 2.173 & 0.068 & 0.94 & $<0.001$ & 66 \\
\hline \multirow[t]{2}{*}{ ST } & Fresh & 0.159 & 0.021 & 2.346 & 0.062 & 0.96 & $<0.001$ & 66 \\
\hline & Dry & 0.100 & 0.013 & 2.343 & 0.063 & 0.96 & $<0.001$ & 66 \\
\hline \multirow[t]{2}{*}{$B R$} & Fresh & 0.233 & 0.056 & 1.781 & 0.113 & 0.79 & $<0.001$ & 66 \\
\hline & Dry & 0.123 & 0.029 & 1.776 & 0.112 & 0.79 & $<0.001$ & 66 \\
\hline
\end{tabular}


Tab. 4 - Biomass equations developed by linear regression using log-transformed data. Two sets of equations are presented, with and without the inclusion of height. Lower root mean squared error (RMSE) and higher adjusted $R^{2}$ indicate higher precision of the models in predicting biomass. (SE a): standard error of coefficient $a$; (SE b): standard error of coefficient $b$; (const.): model constant.

\begin{tabular}{|c|c|c|c|c|c|c|c|c|c|c|c|c|}
\hline $\begin{array}{l}\text { Indep. } \\
\text { variable }\end{array}$ & $\begin{array}{l}\text { Eqn } \\
\text { no }\end{array}$ & Target variable & Equation & $a$ & $b$ & const. & $\begin{array}{c}\text { SE } \\
a\end{array}$ & $\begin{array}{l}\text { SE } \\
b\end{array}$ & RMSE & $N$ & $\operatorname{Adj}-R^{2}$ & $p$-value \\
\hline \multirow[t]{3}{*}{ DBH } & 1 & $\begin{array}{l}\text { Total above-ground } \\
\text { biomass }(A B)\end{array}$ & $\begin{array}{l}\log (A B)=2.173 \cdot \log (D B H)- \\
0.697\end{array}$ & 2.173 & - & -0.697 & 0.068 & - & 0.12 & 66 & 0.94 & $<0.001$ \\
\hline & 2 & Stem biomass (ST) & $\begin{array}{l}\log (S T)=2.361 \cdot \log (D B H)- \\
\quad 1.011\end{array}$ & 2.361 & - & -1.011 & 0.068 & - & 0.12 & 66 & 0.95 & $<0.001$ \\
\hline & 3 & Branch biomass (BR) & $\begin{array}{l}\log (B R)=1.776 \cdot \log (D B H)- \\
0.912\end{array}$ & 1.776 & - & -0.912 & 0.112 & - & 0.20 & 66 & 0.79 & $<0.001$ \\
\hline \multirow[t]{3}{*}{$\begin{array}{l}\text { DBH, } \\
\text { height }\end{array}$} & 4 & $\begin{array}{l}\text { Total above-ground } \\
\text { biomass }(A B)\end{array}$ & $\begin{array}{c}\log (A B)=1.711 \cdot \log (D B H)+ \\
0.680 \cdot \log (\text { Height })-0.918\end{array}$ & 1.711 & 0.680 & -0.918 & 0.152 & 0.203 & 0.11 & 66 & 0.95 & $<0.001$ \\
\hline & 5 & Stem biomass (ST) & $\begin{array}{c}\log (S T)=1.654 \cdot \log (D B H)+ \\
1.040 \cdot \log (\text { Height })-1.334\end{array}$ & 1.654 & 1.040 & -1.334 & 0.132 & 0.176 & 0.10 & 66 & 0.97 & $<0.001$ \\
\hline & 6 & Branch biomass (BR) & $\begin{array}{c}\log (B R)=1.775 \cdot \log (D B H)+ \\
0.002 \cdot \log (\text { Height })-0.912\end{array}$ & 1.775 & 0.002 & -0.912 & 0.272 & 0.364 & 0.20 & 66 & 0.79 & $<0.001$ \\
\hline \multirow[t]{3}{*}{ DRC } & 7 & $\begin{array}{l}\text { Total above-ground } \\
\text { biomass }(A B)\end{array}$ & $\begin{array}{l}\log (A B)=2.405 \cdot \log (D R C)- \\
\quad 1.396\end{array}$ & 2.405 & - & -1.396 & 0.083 & - & 0.10 & 20 & 0.83 & $<0.001$ \\
\hline & 8 & Stem biomass (ST) & $\begin{array}{l}\log (S T)=2.201 \cdot \log (D R C)- \\
\quad 1.723\end{array}$ & 2.201 & - & -1.723 & 0.317 & - & 0.13 & 20 & 0.71 & $<0.001$ \\
\hline & 9 & Branch biomass (BR) & $\begin{array}{l}\log (B R)=2.524 \cdot \log (D R C)- \\
1.698\end{array}$ & 2.524 & - & -1.698 & 0.316 & - & 0.13 & 20 & 0.77 & $<0.001$ \\
\hline \multirow[t]{3}{*}{$\begin{array}{l}\text { DRC, } \\
\text { height }\end{array}$} & 10 & $\begin{array}{l}\text { Total above-ground } \\
\text { biomass }(A B)\end{array}$ & $\begin{array}{c}\log (A B)=1.752 \cdot \log (D R C)+ \\
0.659 \cdot \log (\text { Height })-1.353\end{array}$ & 1.752 & 0.659 & -1.353 & 0.373 & 0.299 & 0.09 & 20 & 0.86 & $<0.001$ \\
\hline & 11 & Stem biomass (ST) & $\begin{array}{c}\log (S T)=0.944 \cdot \log (D R C)+ \\
1.269 \cdot \log (\text { Height })-1.641\end{array}$ & 0.944 & 1.269 & -1.641 & 0.371 & 0.297 & 0.09 & 20 & 0.86 & $<0.001$ \\
\hline & 12 & Branch biomass (BR) & $\begin{array}{c}\log (B R)=2.368 \cdot \log (D R C)+ \\
0.157 \cdot \log (\text { Height })-1.688\end{array}$ & 2.368 & 0.157 & -1.688 & 0.532 & 0.436 & 0.13 & 20 & 0.75 & $<0.001$ \\
\hline
\end{tabular}

served ones (Wilcoxon signed-rank test Tab. S5 in Supplementary material). When we studied the relationship between the fresh and dry biomass weights in each trunk compartment, significantly high positive correlations were found between all dry and fresh equations for both the DRC and DBH categories (Tab. S6 in Supplementary material). The moisture content per compartment was calculated from the fresh and respective dry weights of the sub-samples that were brought to the laboratory from the field. The highest amount of moisture content was found in the $\mathrm{BR}$ (DBH category: 47.7\%, DRC category: $48.7 \%$ ), followed by the $A B$ (DBH category: 40.8\%, DRC category: $44.6 \%)$ and ST sections (DBH category: $37.5 \%$, DRC category: $38.4 \%)$.

\section{Biomass equations based DBH, DRC and} height

The log transformed allometric biomass equations based on DBH, DRC and height are presented in Tab. 4. Overall, adjusted $R^{2}$ was higher in above-ground $(A B)$ and stem biomass (ST) equations when both DBH and height were included as independent variables, compared to those equations based solely on DBH. The root mean squared errors (RMSE) in the $A B$ and ST equations were lower when $\mathrm{DBH}$ and height were included in the biomass equations than in the biomass equations based solely on DBH. However, the adjusted $R^{2}$ and RMSE did not differ between the DBH- and DBH-and-height-based equations for estimating branch biomass (Tab. 4). A similar trend (high adjusted $R^{2}$ and low RMSE) was found in saplings (DRC category) for estimating above-ground and stem biomass when the height and DRC of saplings were included in the model, but this trend was not found in the estimation of branch biomass of saplings (Tab. 4). The slight increase in model precision ( $1 \%$ lower values of RMSE) due to the inclusion of height did not influence the biomass prediction, and as a result, the observed and modelled values from diameter- and diameter-andheight-based models did not differ significantly, except in stem biomass for trees (DBH category) where the inclusion of height significantly reduced the difference between observed and modelled values (Tab. S7 in Supplementary material).

\section{Proportions of stem and branch} biomass in relation to tree size

The proportions of stem (ST) and branch (BR) biomass to the total above-ground biomass (AB) were assessed from the sampled plants. Taller plants had $71 \%$ stem biomass and $29 \%$ branch biomass, whereas shorter plants had $44 \%$ stem biomass and $56 \%$ branch biomass. We found a significant negative correlation between the DBH and proportion of BR biomass for taller plants (Pearson's $r=-0.575, N=66, p<0.001$ ). This implies that leaf and branch biomass decrease with increasing tree size. However, such a dependency on diameter was not observed in shorter plants (Spearman's $\rho=0.127, N=20, p>0.05$ ).

Comparisons of DBH based biomass equations with previously published equations

The equations for the dry biomass of taller plants (DBH category) were compared with published equations for different compartments: total above-ground biomass, stem biomass, and biomass of branches and foliage (Fig. 2). We found that for the total above-ground biomass (AB), all of the equations from past studies (Bartelink 1997, Cienciala et al. 2005, Pretzsch 2000, Santa-Regina et al. 1997, Stankic et al. 2014) significantly overestimated the biomass for the beech trees used in this study (Fig. 3, Tab. S8 in Supplementary material). The slope of the equations indicated that with an increase in $\mathrm{DBH}$, the overestimation by previously published equations became higher.

For the stem biomass, the equations from past studies (Bartelink 1997, Cienciala et al. 2005, Santa-Regina et al. 1997) also overestimated the biomass. Similar to $\mathrm{AB}$, as $\mathrm{DBH}$ increased, this overestimation in stem biomass became significantly higher (Fig. 3, Tab. S8 in Supplementary material). In the dry branch biomass model, the only published equation by Bartelink (1997) underestimated the biomass until a certain diameter, and then overestimated the biomass of larger trees (Fig. 3, Tab. S8 in Supplementary material). 
Fig. 2 - Relationships between $\mathrm{DBH}$ and dry biomass in this study and previous studies for above-ground biomass (a) stem

biomass (b), and biomass of branches and foliage (c)

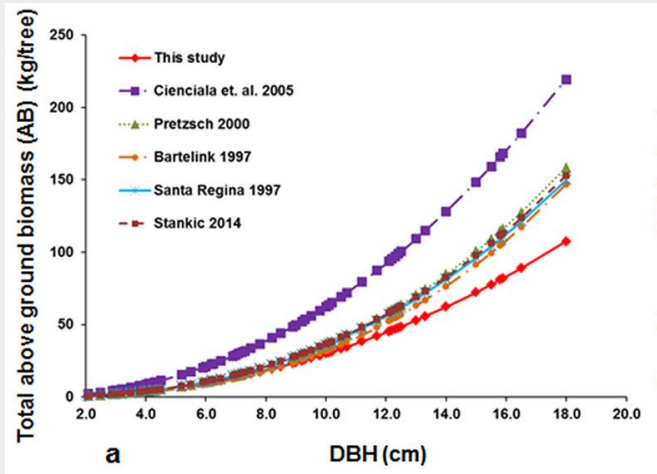

$\mathrm{DBH}(\mathrm{cm})$
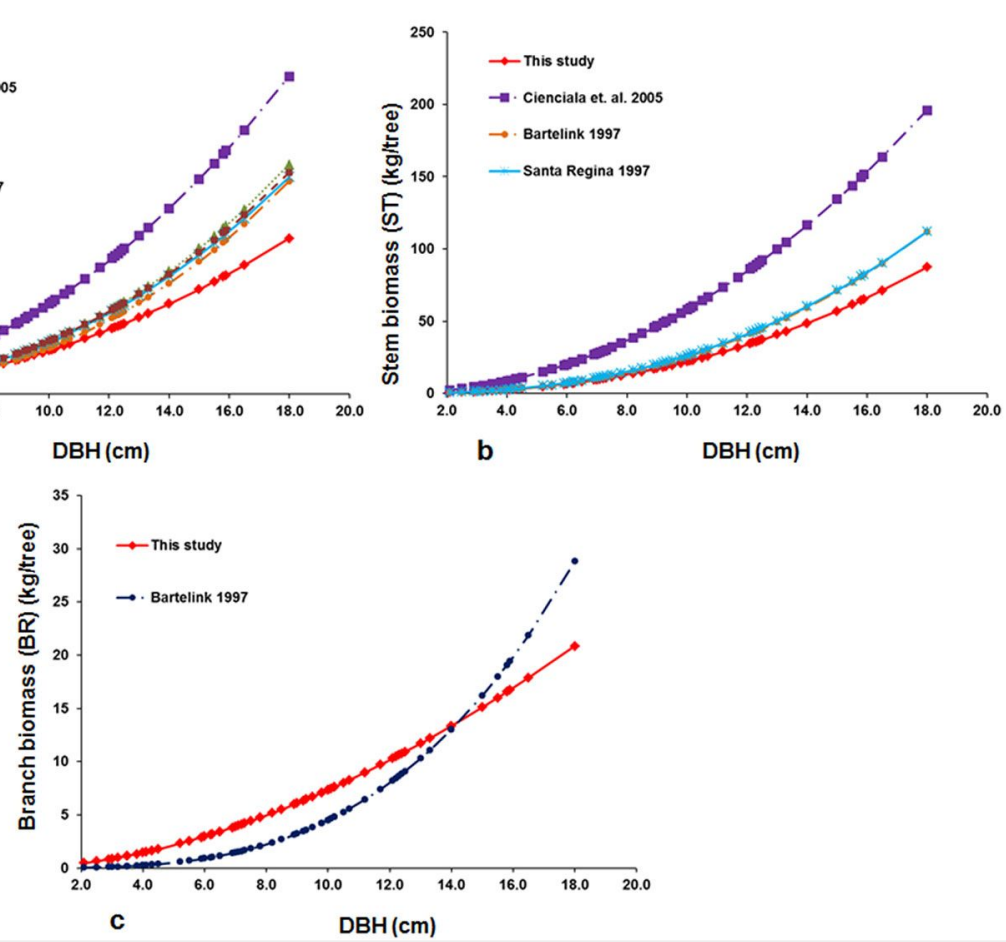

Fig. 3 - Differences between modelled values, observed values and biomass calculated from past studies for dry aboveground biomass (a), dry stem biomass (b), and biomass of dry branches and foliage (c). Line bars indicate the standard error of medians with a $95 \%$ confidence interval. Stars indicate sig nificant differences $(p<0.05)$ after Wilcoxon signed-rank test.

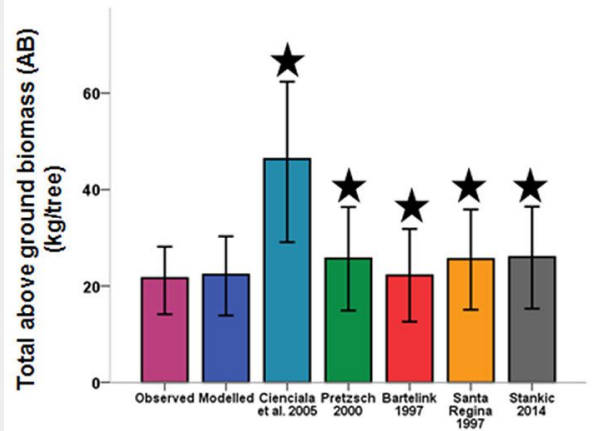

a

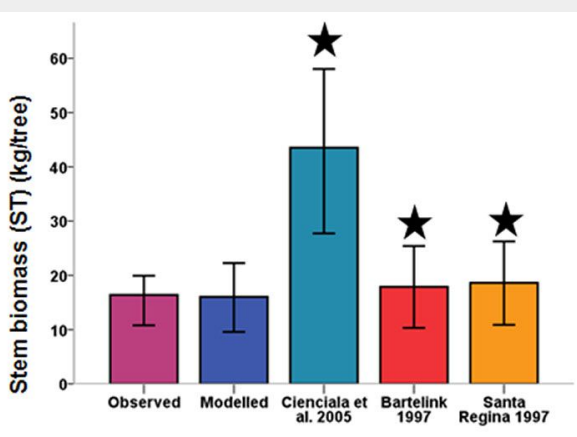

b

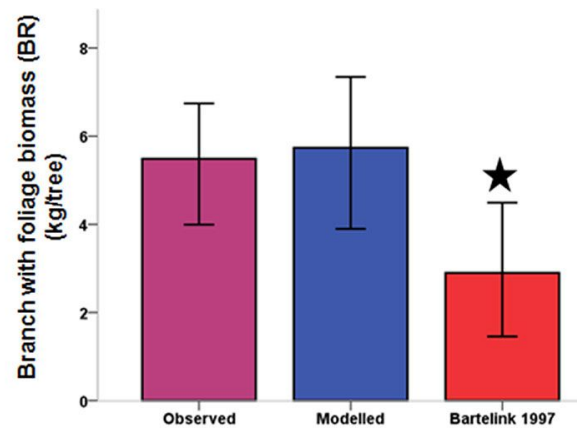

c

\section{Discussion}

We showed that the predicted beech biomass from the equations developed in this study for dry sites differed significantly from the biomass calculated from the existing published equations. Two different trunk compartment-related equations of "stem with bark" and "branch with foliage" differed from the existing equations in the literature. All of the published equations used for the total above-ground biomass calculation for the plants in this study significantly overestimated the biomass when applied to dry sites. The stunted growth of the beech trees growing in dry south-facing hill slopes reduced the overall volume of the trees and therefore decreased the biomass. This supports the results of a previous work (Chakraborty et al. 2013) studying the growth of beech saplings and trees on a dry south-facing outcrop in the Black Forest near the city of Freiburg (Germany).

In general, the stem was the main portion contributing to the above-ground biomass. This supports the results of previous stud- ies on beech trees (Cienciala et al. 2005, Bartelink 1997, Santa-Regina et al. 1997). However, this trend changed with the size of the trees. In shorter plants, branches with green foliage contributed a significantly higher amount of biomass, with a gradual decline observed in taller plants, contrary to the results of a study by Bartelink (1997). All five forest stands were located on dry, south-facing hill slopes where beech trees were regenerating in old coppiced oak stands near their drought limit. Taller beech trees might have shed 
their branches and leaves to adjust the proportion of above- and below-ground biomass as a survival strategy under drough stress in dry sites, as well as to foster vertical growth to compete for light in the canopy layer. The high height-to-diameter ratio of 112 in taller plants also supports this phenomenon. Conversely, shorter beech saplings had stunted growth (i.e., low height-to-diameter ratio of 89 ) and might have preferred more radial stem growth and lateral branch growth to capture light than shoot elongation. For shorter plants, it was profitable to maintain a shorter height for longer periods to optimize the water supply to the top and to reduce the vulnerability of xylem to cavitation due to hydraulic failure in dry sites. Chakraborty et al. (2013) reported that the beech saplings growing under the canopy of oak trees in dry sites can prolong their sapling stage for decades to avoid droughtinduced mortality. Maintenance of such stunted growth in beech trees was possible because their high tolerance to shade allowed the plants to endure drought stress (Weiner 1990, Peters 1997, Ellenberg 2009).

Site-specific adaptation as described above usually occurs in tree species to optimize the use of water and light resources (Schulze et al. 2005) that eventually influence tree morphological traits (e.g., trees become stunted). Such adaptations at the level of the autecology of species influence the synecology of environmentally stress ed forest ecosystems (Evenari et al. 1982) and alter individual trees, as well as the stand biomass. Previous biomass equations developed for beech trees from high forests are not suited to capture this morphological adaptation of trees at similar age growing on dry rendzina soil.

In the first section of our model building, we used a power function. Use of a power function to scale the diameter to the biomass relationship supports the West, Brown and Enquist model (WBE model) of general plant allometry (Enquist et al. 2000, Enquist 2002, Brown et al. 2000 , West et al. 1997, 1999a, 1999b). The WBE model showed that the diameter and biomass allometry of 73 temperate tree species had an average power component (i.e., parameter $b$ in Tab. 2 and Tab. 3) of 2.611 and hence follow the $8 / 3$ rule. In this study, the value of this component was 2.408 and 2.173 for the DRC and DBH categories, respectively (Tab. 2 and Tab. 3). This shows that in shorter and stunted beech plants (the DRC category), the allometry of biomass and size tends to be closer to the overall value of 2.611 , as a slower shoot elongation was compensated by lateral growth of the branches. However, in taller plants, the value of this component was $17 \%$ lower than the overall value, possibly the result of a low proportion of branch and foliage biomass. Thus, our results sup port the evidence that European beech trees growing in drier sites deviate from the temperate allometric relationship of tree size and biomass and may not always follow the above-mentioned $8 / 3$ rule.

The inclusion of height in log transformed linear models did not influence the predictions for overall above-ground biomass and branch biomass. However, it did improve the estimation of stem biomass. This outcome is reasonable for stem biomass because tree height and stem taper are correlated and might be influenced by stand density, species composition, tree social class and site quality.

\section{Conclusions}

Within the context of central European forests, the biomass equations developed for beech trees growing in dry sites in this study may be very useful to researchers and foresters for the accurate quantification of the biomass of beech trees. Particularly, these equations can be used for beech trees growing under oak forests in dry sites where the size of trees is relatively smaller due to stunted growth, rather than trees growing in fertile and well-drained sites. Such forest stands can be found on the hilly slopes with calcareous rendzina soils in southern Germany, in the plateau regions of Switzerland and in the Jura and Vosges mountains of France where beech is one of the important tree species establishing in abandoned oak forests. These forest stands are not commercially managed today due to lower financial profitability; hence, they are often left for protection to fulfill biodiversity conservation and climate change mitigation goals. Biomass equations from productive and high forests are being used for stunted beech trees growing on dry sites due to the unavailability of proper site-specific equations. Therefore, our equations for beech trees will ensure proper accounting of the carbon stocks in forest stands from similar sites. Tree diameter can be used as the main independent variable for calculating the total above-ground biomass and the biomass of branches and foliage, although the tree height should be considered in the case of stem biomass. In addition to DBH-based equations, we developed novel DRC-based biomass equation for understory beech plants. Previous studies on beech biomass ignored the young beech plants of the forest regeneration layer but several European countries, such as Germany, France, Italy, Switzerland and Sweden, emphasized the recording of size and frequency data for trees growing in the regeneration layer during the National Forest Inventory, necessitating the development of species-specific DRC-based biomass equations (Tomppo et al. 2010). The DRC-based equations developed in this study would also allow for exact estimations of biomass for beech plants with stunted growth, a common phenomenon in dry forest sites. In conclusion, the fundamental allometric relationship between tree size and biomass could be influenced by the site level factors (e.g., poor available soil water storage capacity), warranting future research on other tree species with wide habitat ranges similar to that of European beech.

\section{Acknowledgments}

We gratefully acknowledge the Heinrich Böll Foundation for awarding a PhD scholarship to TC (grant number: P040244). We are also thankful to: the Environment, Society and Global Change Graduate School of the University of Freiburg; to the Müller Fahnnenberg Foundation of the University of Freiburg, Wissenschaftlische Gesellschaft Freiburg; to the GFH Foundation Freiburg, to the Georg Ludwig Hartig Foundation, and to BLNN Freiburg for providing financial support to TC to undertake field and laboratory works. We are thankful to Georgios Skiadaresis, Nicolas Schoof and Jan Heckmann for assisting in field data collection, tree harvesting, transportation of samples and laboratory analysis. We sincerely thank the forest and municipal administrations of Müllheim, ÖschingenMössingen, Klettgau in Baden-Württemberg, Germany and Wilchingen in Canton Schaffhausen, Switzerland for providing permission for the tree felling to conduct this research. We are thankful to two anonymous reviewers for providing valuable suggestions to improve the previous version of the manuscript.

TC and AR jointly developed the research concept and study designs. TC collected field data, performed all laboratory and statistical analyses and wrote the manuscript. SS helped in field data collection and provided useful suggestions in this research. SS and AR commented on a preliminary version of this manuscript.

\section{References}

Bartelink HH (1997). Allometric relationships for biomass and leaf area of beech (Fagus sylvatica L). Annals of Forest Science 54 (1): 39-50. - doi: 10.1051/forest:19970104

BMEL (2014). The forest of Germany - Results from third national forest inventory. Federal Ministry of Nutrition and Agriculture, Berlin, Germany, pp. 56.

Brown JH, West GB, Enquist BJ (2000). Scaling in biology. In: "Scaling in biology: patterns and processes, causes and consequences" (West GB ed). Oxford University Press, Oxford, UK, pp. 167-198. [online] URL: http://books.google. com/books?id=3OwpPgGv29UC

Chakraborty T (2010). Effect of soil drought on vitality and growth on juvenile and understorey beech (Fagus sylvatica L.) trees: case study from a rocky gneiss outcrop near Freiburg, Black Forest, Germany. Master Thesis, University of Freiburg, Germany, pp. 74. [online] URL: http://www.freidok.uni-freiburg.de/data/8066 Chakraborty T, Saha S, Reif A (2013). Decrease in available soil water storage capacity reduces vitality of young understorey European beeches (Fagus sylvatica L.): a case study from the Black Forest, Germany. Plants 2 (4): 676698. - doi: 10.3390/plants2040676 
Cienciala E, Cerny M, Apltauer J, Exnerova Z (2005). Biomass functions applicable to European beech. Journal of Forest Science (Prague) 51 (4): 147-154.

Coll L, Balandier P, Picon-Cochard C (2004). Morphological and physiological responses of beech (Fagus sylvatica) seedlings to grass-induced belowground competition. Tree Physiology 24 (1): 45-54. - doi: 10.1093/treephys/24.1.45 Ellenberg H (2009). Vegetation Ecology of central Europe. Cambridge University Press, Cambridge, UK. pp. 731.

Enquist BJ (2002). Universal scaling in tree and vascular plant allometry: toward a general quantitative theory linking plant form and function from cells to ecosystems. Tree Physiology 22 (15-16): 1045-1064. - doi: 10.1093/treephys/ 22.15-16.1045

Enquist BJ, West GB, Brown JH (2000). Scaling in Biology. In: "Quarter-power scaling in vascular plants: Functional basis and ecological consequences" (West GB ed). Oxford University Press, Oxford, UK, pp. 167-198.

Evenari M, Shanan L, Tadmor N (1982). The Negev: the challenge of a desert. Harvard University Press, Cambridge, UK. pp. 437.

Gärtner S, Reif A, Xystrakis F, Sayer U, Bendagha $\mathrm{N}$, Matzarakis A (2008). The drought tolerance limit of Fagus sylvatica forest on limestone in southwestern Germany. Journal of Vegetation Science 19 (6): 757-768. - doi: 10.3170/2008-818442

Gauer J, Aldinger E (2005). Waldökologische Naturräume Deutschlands - Forstliche Wuchsgebiete und Wuchsbezirke, mit Karte 1:100.000 [Forest ecological growing zone of Germany: forest growing zone and growing area, with map of 1:100.000]. Report of the German Association of Forest Site Classification and Forest Tree Improvement, Henkel Druck, Stuttgart, Germany, pp. 324. [in German]

IBM (2011). Statistical Package for the Social Sciences (SPSS v. 20). SPSS Inc. 20, New York, USA, pp. 428.

Kauter D, Lewandowski I, Claupein W (2003). Quantity and quality of harvestable biomass from Populus short rotation coppice for solid fuel use - a review of the physiological basis and management influences. Biomass and Bioenergy 24 (6): 411-427. - doi: 10.1016/Sog619534(02)00177-0

Kohler M, Kockemann B, Peichl M, Schmitt J, Reif A (2006). Impacts of the drought 2003 on the crown condition of suppressed and intermediate beech trees (Fagus sylvatica L.) at the ecotone between beech and downy oak forest in the nature reserve Innerberg, Suedbaden. German Journal of Forestry and Hunting 177 (5): 86-91.

Peters R (1997). Beech forests. Geobotany Series 24, Kluwer Academic Publishers, Dordrecht, The Netherlands, pp. 169. - doi: 10.1007/978-94015-8794-5

Peuke AD, Schraml C, Hartung W, Rennenberg H (2002). Identification of drought-sensitive beech ecotypes by physiological parameters. New Phytologist 154 (2): 373-387. - doi: 10.1046/ j.1469-8137.2002.00400.x

Pretzsch H (2000). Die Regeln von Reineke, Yoda und das Gesetz der räumlichen Allometrie [The rules by Reineke, Yoda and the law of spatial allometry]. German Journal of Forestry and Hunting 171: 205-210. [in German]

Pyttel P (2011). Aspekte einer nachhaltigen Bewirtschaftung durchgewachsener Niederwälder [Aspects of sustainable management in forests developed by coppicing]. PhD Thesis, Institute of Silviculture, Albert-Ludwigs-Universität Freiburg, Germany, pp. 166. [in German]

Santa-Regina I, Tarazona T, Calvo R (1997). Aboveground biomass in a beech forest and a Scots pine plantation in the Sierra de la Demanda area of northern Spain. Annals of Forest Science 54 (3): 261-269. - doi: 10.1051/ forest:19970304

Sayer U (2000). Die Ökologie der Flaumeiche (Quercus pubescens Willd.) und ihrer Hybriden auf Kalkstandorten an ihrer nördlichen Arealgrenze (Untersuchungen zu Boden, Klima und Vegetation) [The ecology of downy oak (Quercus pubescens Wild.) and their hybrids on calcareous sites at their northern distribution limit (study on soil, climate and vegetation)]. Dissertationes Botanicae Cramer vol 340, Stuttgart, Germany, pp. 198. [in German]

Schulze E-D, Beck E, Muller-Hohenstein K (2005). Plant Ecology. Springer, Berlin, Heidelberg, Germany, pp. 702.

Standortskartierung A (2003). Forstliche Standortsaufnahme [Forest site classification] $\left(6^{\text {th }}\right.$ edn). IHW-Verlag und Verlagsbuchhandlung, Eching, Munich, Germany, pp. 352. [in German] Stankic I, Marence J, Vusic D, Zecic Z, Benkovic Z (2014). Structure of the common beech aboveground tree biomass in different stand conditions. Sumarski List 138 (9-10): 439-450. [online] URL: http://hrcak.srce.hr/index.php?show=clan ak\&id_clanak_jezik=197165

Suchomel C, Pyttel P, Becker G, Bauhus J (2012). Biomass equations for sessile oak (Quercus petraea (Matt.) Liebl.) and hornbeam (Carpinus betulus L.) in aged coppiced forests in southwest Germany. Biomass and Bioenergy 46: 722730. - doi: 10.1016/j.biombioe.2012.06. 021

Tomppo E, Gschwantner T, Lawrence M, McRoberts RE (2010). National forest inventories: pathways for common reporting. Springer, London, UK and New York, USA, pp. 612.

Weiner J (1990). Asymmetric competition in plant-populations. Trends in Ecology and Evolution 5 (11): 360-364. - doi: 10.1016/0169-5347 (90)90095-U

West GB, Brown JH, Enquist BJ (1997). A general model for the origin of allometric scaling laws in biology. Science 276 (5309): 122-126. - doi: 10.1126/science.276.5309.122

West GB, Brown JH, Enquist BJ (1999a). A general model for the structure and allometry of plant vascular systems. Nature 400 (6745): 664-667. - doi: 10.1038/23251
West GB, Brown JH, Enquist BJ (1999b). The fourth dimension of life: fractal geometry and allometric scaling of organisms. Science 284 (5420): 1677-1679. - doi: 10.1126/science.284.54 20.1677

WSL (2015). Swiss national forest inventory. Swiss Federal Institute for Forest, Snow and Landscape Research - WSL, Zürich, Switzerland. [online] URL: http://www.Ifi.ch/index-en.php

Zianis D, Muukkonen P, Makipaa R, Mencuccini $M$ (2005). Biomass and stem volume equations for tree species in Europe. Silva Fennica Monographs 4, pp. 63.

\section{Supplementary Material}

Tab. S1 - Height and diameter of beech saplings $(a-N=69)$ and trees $(b-N=161)$ inventoried in 5 stands (DRC = diameter at root collar, $\mathrm{DBH}=$ diameter at breast or 1.3 $\mathrm{m}$ height).

Tab. S2 - Primary data of the beech saplings (i.e., DRC category $-\mathrm{N}=20$ ) which were used for parameterization of allometric equations.

Tab. S3 - The harvested samples of beech trees $(N=66)$ for (i.e. DBH category) and primary data used for parameterization of allometric equations.

Fig. S1 - Relationship between diameter and height for the sampled trees; a: trees in DBH category, b: saplings in DRC category.

Tab. S4 - Test of significance between observed and modelled values calculated from DRC based allometric equations with power functions.

Tab. S5 - Significance testing for biomass models between observed and modelled biomass calculated from DBH based allometric equations with power functions.

Tab. S6 - Correlation results between modelled weights of fresh and dry biomass in DRC and DBH categories.

Tab. S7 - Comparisons between observed values in dry biomass and modelled values from solely diameter based plus diameter and height based equations developed by linear regressions in DBH and DRC categories.

Tab. S8 - Significance testing between modelled biomass of this study and different biomass predicted by power function models from literature in plants of $\mathrm{DBH}$ category.

Link: Chakraborty_1881@supplo01.pdf 